\title{
Hyaluronan Decreases Surfactant Inactivation In Vitro
}

\author{
KAREN W. LU, JON GOERKE, JOHN A. CLEMENTS, AND H. WILLIAM TAEUSCH
}

Departments of Pediatrics [K.W.L., J.A.C., H.W.T.] and Physiology [J.G] and the Cardiovascular

Research Institute [J.G., J.A.C.], University of California, San Francisco, San Francisco, CA 94110

\begin{abstract}
Hyaluronan (HA) is an anionic polymer and a constituent of alveolar fluid that can bind proteins, phospholipids, and water. Previous studies have established that nonionic polymers improve the surface activity of pulmonary surfactants by decreasing inactivation of surfactant. In this work, we investigate whether HA can also have beneficial effects when added to surfactants. We used a modified pulsating bubble surfactometer to measure mixtures of several commercially available pulmonary surfactants or native calf surfactant with and without serum inactivation. Surface properties such as equilibrium surface tension, minimum and maximum surface tensions on compression and expansion of a surface film, and degree of surface area reduction required to reach a surface tension of $10 \mathrm{mN} / \mathrm{m}$ were measured. In the presence of serum, addition of HA dramatically improved
\end{abstract}

\section{ABSTRACT}

the surface activities of all four surfactants and in some cases in the absence of serum as well. These results indicate that HA reduces inactivation of surfactants caused by serum and add evidence that endogenous HAs may interact with alveolar surfactant under normal and abnormal conditions. (Pediatr Res 57: 237-241, 2005)

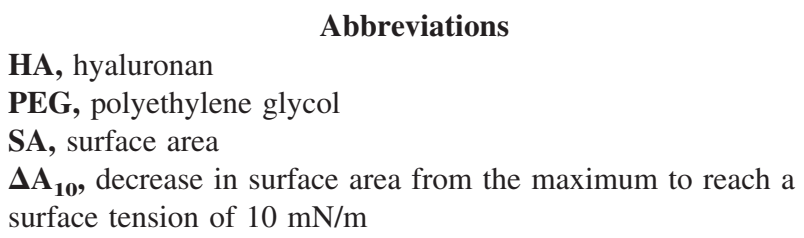

Over the past decade, pulmonary surfactant replacement has revolutionized the therapy of respiratory distress syndrome of premature infants (1-3). However, effects of surfactant therapy are less dramatic when used to treat lung diseases associated with acute lung injury and acute respiratory distress syndrome (4-7). The less successful clinical response in these diseases may be due in part to surfactant inactivation caused by leakage of plasma and inflammatory products into the alveoli. In the presence of inactivating substances, surface activity of alveolar surfactant is adversely affected, worsening overall lung function $(8,9)$.

Variation in susceptibility to inactivation exists among therapeutic surfactants. Many studies have reported that surfactantassociated proteins help resist inactivation caused by a variety of factors (6). We and others have found that the addition of nonionic polymers [principally polyethylene glycol (PEG), or

Received August 21, 2003; accepted July 14, 2004

Correspondence: Karen W. Lu, M.D., San Francisco General Hospital, Department of Pediatrics, MS 6E, 1001 Potrero Avenue, San Francisco, CA 94110; e-mail: klu@sfghpeds.ucsf.edu

Supported by National Institutes of Health, Heart, Lung, and Blood Institute Grants RO1 HL 66410 (Department of Pediatrics, University of California, San Francisco) and RO1 HL 24075 (Department of Physiology and the Cardiovascular Research Institute, University of California, San Francisco).

DOI: 10.1203/01.PDR.0000150726.75308.22 dextran] further reduces surfactant inactivation by serum, meconium, or other substances in vitro (10-12). In vivo studies also demonstrate that the addition of nonionic polymers to therapeutic surfactants improves pulmonary function after lung injury caused by meconium, albumin, hydrochloric acid, milk acid, or endotoxin (11,13-16).

The successful experiments with nonionic polymers led us to consider using ionic polymers. In this study, we investigated whether hyaluronan (HA) has effects on pulmonary surfactants that are similar to those described for dextran and PEG. HA is a nonsulfated, polymeric glycosaminoglycan (mucopolysaccharide) of $N$-acetyl-glucosamine linked $\beta-1,4$ to glucuronic acid, which is linked $\beta-1,3$ to $N$-acetylglucosamine, etc. Unlike PEG or dextran, HA, an anionic polymer, is a natural, ubiquitous substance in the body. However, HA (like PEG and dextran) shares the ability to bind water but has much greater binding capacity. In addition, HA can interact with phospholipids to form various complexes that depend on the molecular weight of HA (17). HA and other glycosaminoglycans are secreted by alveolar epithelial cells $(18,19)$, and early papers already speculated that complex carbohydrates may interact in important ways with pulmonary surfactant under normal conditions in the alveoli (20-22). More recently, Bray (23) suggested that HA has important extracellular functions that affect 
lung surfactant. To study the effects of HA on samples of surfactants that are derived from several animal species, we compared the surface activity of three commercial pulmonary surfactants approved for human use (Survanta, Curosurf, Infasurf) and native calf surfactant, with and without HA, and also with and without serum used as an inhibitor of surfactant function.

\section{METHODS}

Materials. HA of 250 and $100 \mathrm{kD}$ were a gift from GlycoMed Research (Hastings-on-Hudson, NY). Molecular weight determinations were carried out by the manufacturer using extrapolation of viscosity measurements to zero concentration, a method that gives estimates within $10 \%$ of direct measures. These HA preparations contain $<0.01 \%$ protein and a ratio of hexuronic acid to hexosamine of 1:1 (characteristic of HA). HA of $1240 \mathrm{kD}$ was purchased from Sigma Chemical Co. (St. Louis, MO) with a protein content of $0.07 \%$. Lipopolysaccharide concentrations in samples of HA used in these studies were 0.015-0.025 EU/mg of HA determined by chromogenic Limulus amoebocyte assay (QLC-1000; BioWhittaker, Walkersville, MD). The three HA preparations were isolates from Streptococcus fermentation and were used as supplied.

Survanta was obtained from our neonatal intensive care unit. Curosurf was purchased from Dey Laboratory (Napa, CA). Infasurf was a gift from Forest Laboratories (New York, NY). Native surfactant was obtained by saline bronchoalveolar lavage of freshly obtained calf lung. The recovered lavage fluid was centrifuged at $500 \times g$ for $10 \mathrm{~min}$ to remove cellular debris. The supernatants then were centrifuged at $17,000 \times g$ for $2 \mathrm{~h}$ at $10^{\circ} \mathrm{C}$. The pelleted material was lyophilized, stored at $-80^{\circ} \mathrm{C}$, and reconstituted just before use with distilled water. The concentration of phospholipids in native calf surfactant was determined by measuring lipid phosphorus after Bligh-Dyer extraction $(24,25)$. Reported protein content of native calf surfactant is $10 \%$ of the total weight with SP-A 4\% and SP-B and C each 1\% (26). All of the surfactants were diluted with a buffered solution of $0.9 \% \mathrm{NaCl}$ and $5 \mathrm{mM}$ of HEPES at a $\mathrm{pH}$ of 6.5. The final concentrations of Survanta, Curosurf, and Infasurf were $1.25 \mathrm{mg}$ weight phospholipid $/ \mathrm{mL}$, and native surfactant was $1.0 \mathrm{mg} / \mathrm{mL}$. HA in dry powder form was added to the surfactant and mixed by Vortex for $\sim 60 \mathrm{~s}$ at room temperature to a final concentration of $0.25 \%$ (wt/vol). This concentration was chosen from pilot experiments. Serum obtained from normal adult laboratory volunteers was used as a nonspecific inhibitor of surfactant activity. The serum was frozen at $-20^{\circ} \mathrm{C}$ until use, then thawed and added to the surfactant mixtures and mixed by Vortex for $20 \mathrm{~s}$ before testing (within 30 min). The smallest volume of serum that when added to $1 \mathrm{~mL}$ of surfactant suspension was able to raise the minimum surface tension to $>14 \mathrm{mN} / \mathrm{m}$ was used for inactivation of each surfactant $(5 \mu \mathrm{L}$ of serum $/ \mathrm{mL}$ for Curosurf and Infasurf and $10 \mu \mathrm{L}$ for Survanta and native surfactant, equivalent to $350-700$ $\mu \mathrm{g}$ of serum protein).

Surface activity. Surface activity was measured in a modified pulsating bubble surfactometer (Electronetics, Buffalo, NY) using a technique to prevent wetting of the capillary tube (27). The temperature of the $25-\mu \mathrm{L}$ sample chamber was maintained at $37^{\circ} \mathrm{C}$ throughout. Pressure measurements for the device were calibrated electronically according to the manufacturer's instructions and checked with a water manometer. Surface tension measurements were calibrated using pure fluids with known surface tensions.

Equilibrium surface tension was defined as the value of surface tension $~ 30$ $\mathrm{s}$ after the formation of a static microbubble of $0.40 \mathrm{~mm}$ radius. We used this measure as an approximate index of the amount of surface active material that reached the air-water interface before cycling (inflation-deflation) of the microbubble. Thereafter, the microbubble was cycled at $20 /$ min with radii changing between 0.40 and $0.55 \mathrm{~mm}$. Minimum and maximum surface tensions were recorded at the 10th cycle $(60 \mathrm{~s})$ and after $5 \mathrm{~min}$. The surface tension was calculated by use of the Laplace formula $\mathrm{P}=2 \mathrm{ST} / \mathrm{r}$, where ST is the surface tension, $\mathrm{P}$ is the inflating pressure, and $\mathrm{r}$ is the radius of the assumed spherical bubble.

We also calculated the percentage reduction in bubble surface area (SA) from its maximum value to that required for the surface tension to reach a value of $10 \mathrm{mN} / \mathrm{m}$. This measurement $\left(\Delta \mathrm{A}_{10}\right)$ was made $5 \mathrm{~min}$ after the start of bubble cycling. The parameter $\Delta \mathrm{A}_{10}$ reflects film compressibility: films with low compressibility (a low $\Delta \mathrm{A}_{10}$ ) produce a large decrease in surface tension with a relatively small decrease in SA. $\Delta \mathrm{A}_{10}$ also indicates the ability of preformed films to respread after repeated expansions and reductions of SA. The formula is $\Delta \mathrm{A}_{10}=[(\max \mathrm{SA}-\mathrm{SA} @ 10 \mathrm{mN} / \mathrm{m}) / \mathrm{max} \mathrm{SA}] \times 100 \%$. If the surface tension did not reach $10 \mathrm{mN} / \mathrm{m}$, then the actual $\Delta \mathrm{A}_{10}$ values would have had to be greater than $47 \%$ because that is the difference in SA between the maximum and minimum bubble areas in our pulsating bubble surfactometer. In all, there were six measures of surface activity: minimum and maximum surface tensions at the 10 th cycle and after five minutes, $\Delta \mathrm{A}_{10}$, and equilibrium surface tension.

Analysis. The data are presented as means \pm SEM. Measurements were analyzed by one-way ANOVA using SigmaStat software (SPSS Science, Chicago, IL). Comparisons between pairs of groups were done using the Tukey test or the Kruskal-Wallis test when necessary to correct for multiple comparisons. A $p \leq 0.05$ was taken to indicate statistical significance.

\section{RESULTS}

The six measures of surface activity previously defined were obtained for four surfactants, with and without the addition of HAs of three different molecular weights, in the presence or absence of serum. In general, surface activity of Survanta, Infasurf, Curosurf, and native surfactant was affected by the addition of HA before and (most dramatically) after serum inactivation. Equilibrium surface tension (surface tension after $30 \mathrm{~s}$ of incubating before cycling) is least affected by HA, and $\Delta \mathrm{A}_{10}$ is affected the most. Overall, the changes caused by the addition of HA improved surface activity.

Surface activity in the absence of serum or HA. Mean equilibrium surface tension values for the four surfactants ranged from $22 \pm 1$ to $25 \pm 1 \mathrm{mN} / \mathrm{m}$, with no significant differences among them. After 10 cycles (total elapsed time of $60 \mathrm{~s}$ from bubble formation), the average minimum surface tension for Survanta was $3 \mathrm{mN} / \mathrm{m}$, whereas the other surfactants had values $>10 \mathrm{mN} / \mathrm{m}$. All surfactants reached a minimum surface tension $<4 \mathrm{mN} / \mathrm{m}$ after 5 min of cycling. Survanta had the highest maximum surface tension, which was 40 $\pm 1 \mathrm{mN} / \mathrm{m}$ after the 10th cycle and $41 \pm 2 \mathrm{mN} / \mathrm{m}$ at $5 \mathrm{~min}$. Curosurf had the lowest maximum surface tension, which was $30 \pm 1 \mathrm{mN} / \mathrm{m}$ after the 10 th cycle and $35 \mathrm{mN} / \mathrm{m}$ after $5 \mathrm{~min}$ of cycling. SA reduction of $17-27 \%$ was required for the surfactants to reach a surface tension of $10 \mathrm{mN} / \mathrm{m}_{\left(\Delta \mathrm{A}_{10}\right)}$.

Addition of HA. In general, the addition of HA improved surface activity. Considering all combinations of surfactants and molecular weights of HA, approximately one third of the minimum surface tensions and $\Delta \mathrm{A}_{10}$ s were significantly improved (Figs. $1 A$ and $2 A$ ). However, the maximum surface tension with $1240-\mathrm{kD}$ HA was significantly elevated for Survanta and native surfactant (Table 1). There was little effect associated with the addition of HA on the mean equilibrium surface tension.

Addition of serum. We adjusted the amount of serum to ensure that minimum surface tensions remained above 14 $\mathrm{mN} / \mathrm{m}$, that is, that inactivation occurred. When serum was added, the equilibrium surface tension was typically $\sim 10$ $\mathrm{mN} / \mathrm{m}$ above the normal values absent serum. The maximum surface tension was slightly higher than without serum inactivation (Table 1). The value for $\Delta \mathrm{A}_{10}$ was $>47 \%$ because minimum surface tensions for all surfactants remained $>10$ $\mathrm{mN} / \mathrm{m}$ by design. 
A

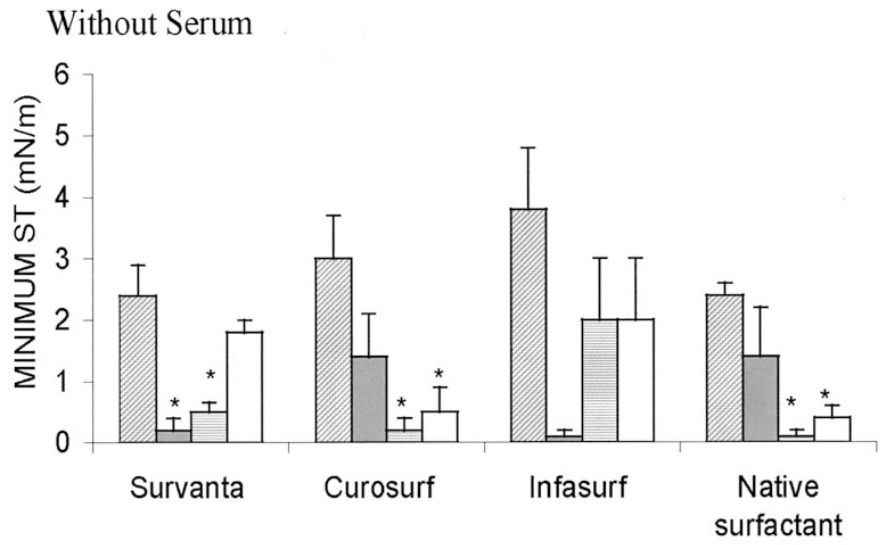

B

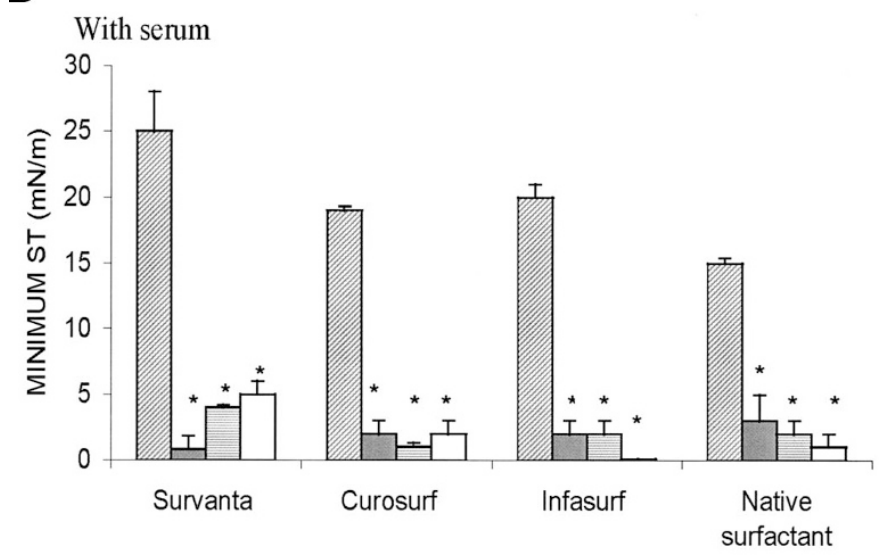

Figure 1. Minimum surface tension after $5 \mathrm{~min}$ of cycling is shown for four surfactants without $(A)$ and with $(B)$ serum inactivation with or without HA $1240 \mathrm{kD}, 250 \mathrm{kD}$, or $100 \mathrm{kD}(n=5)$. , surfactant without HA; $\square$, surfactant with HA $1240 \mathrm{kD}$; 貝, surfactant with HA $250 \mathrm{kD}$; $\square$, surfactant with HA 100 $\mathrm{kD} ; * p \leq 0.05$ for comparisons of HA-treated $v s$ untreated samples (by ANOVA corrected for multiple comparisons).

Addition of both serum and HA. Minimum surface tension was dramatically improved (compared with mixtures that did not contain HA). Values obtained were comparable to those without serum inactivation (Fig. 1). Also, values of $\Delta \mathrm{A}_{10}$ seemed similar to those for surfactants alone (no HA and no serum inactivation; Fig. 2).

Effects of HA on different surfactants. For Survanta, all six measures of surface activity were affected significantly with the addition of at least one of the HAs in the absence of serum, and all measures were affected except for maximum surface tension at the 10th cycle with serum inactivation. For Curosurf, all measures except equilibrium surface tension and maximum surface tension at $5 \mathrm{~min}$ were significantly altered by HA in the absence of serum, and all six measures were affected significantly by one or more HA additives after addition of serum. For Infasurf, $\Delta \mathrm{A}_{10}$ was the only measure of surface activity that was markedly affected by HA in the absence of serum; however, all but the equilibrium surface tension were affected by HA in the presence of serum. For native surfactant, all measures except for equilibrium surface tension were improved by the addition of one or more of the HAs with and without serum.
A

Without Serum

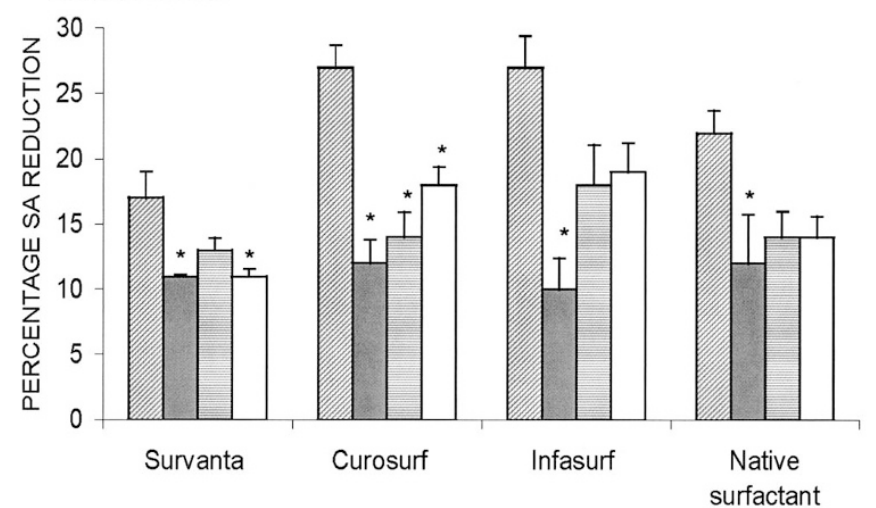

B

With serum

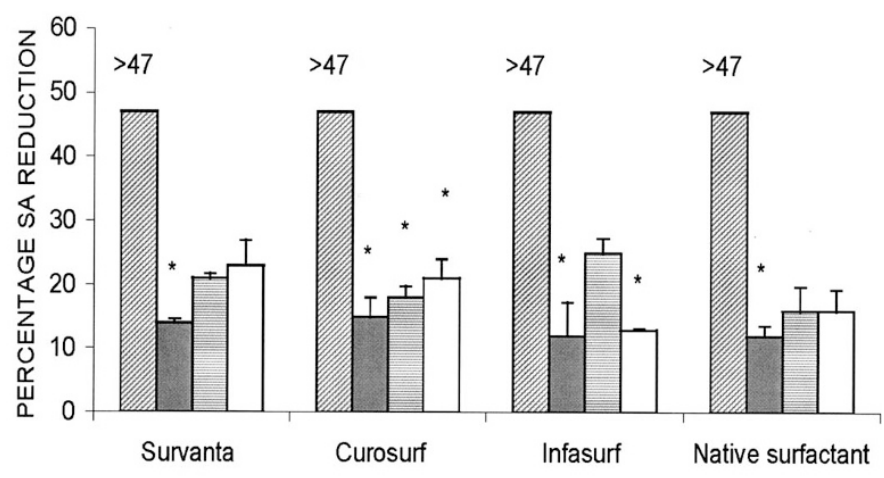

Figure 2. $\Delta \mathrm{A}_{10}$ values are shown for four surfactants without $(A)$ and with $(B)$ serum inactivation with or without HA $1240 \mathrm{kD}, 250 \mathrm{kD}$, or $100 \mathrm{kD}(n=5)$. Bars are the same as in Fig. 1. ${ }^{*} p \leq 0.05$ for comparisons of HA-treated $v s$ untreated samples (by ANOVA corrected for multiple comparisons). For $\Delta \mathrm{A}_{10}$ values that are $>47 \%$, we used a value of $47 \%$ to carry out the statistical analysis, a substitution that increases $p$ values relative to what they would be if $\Delta \mathrm{A}_{10}$ values $>47 \%$ were measurable.

General effects of HA molecular weight. Overall, $1240 \mathrm{kD}$ improved measures of surface activity more than the two lower molecular weight HAs. For example, with Survanta in the absence of serum, 1240-kD HA improved three of six measures of surface activity to a significantly greater degree than 250-kD HA and five of six measures to a significantly greater degree than $100-\mathrm{kD}$ HA. The differences associated with different molecular weight HAs was least apparent with Curosurf. For Curosurf, only four surface activity measures out of 12 (six with and six without serum inactivation) were improved to a greater degree with $1240-\mathrm{kD}$ HA than with lower molecular weight HAs. With serum, the maximum surface tension was significantly increased both at the 10th cycle and after $5 \mathrm{~min}$ in the presence of 1240-kD HA for Survanta, Infasurf, and native surfactant. Whereas the maximum surface tensions for those surfactants with 1240-kD HA mixtures were significantly increased, the minimum surface tensions were significantly decreased to a much greater degree. Lower molecular weight HA was associated in only one case with significantly elevated maximum surface tension (Survanta, serum, 100-kD HA), but in most cases, there was a trend (nonsignificant) toward lower 
Table 1. Maximum surface tensions are shown for four surfactants with three molecular weights of HA in the presence or absence of serum $^{*}$

\begin{tabular}{|c|c|c|c|c|c|c|c|c|}
\hline & \multicolumn{4}{|c|}{ Survanta +} & \multicolumn{4}{|c|}{ Curosurf +} \\
\hline & & HA 1240 & HA 250 & HA 100 & & HA 1240 & HA 250 & HA 100 \\
\hline & No HA & $\mathrm{kD}$ & $\mathrm{kD}$ & $\mathrm{kD}$ & No HA & $\mathrm{kD}$ & $\mathrm{kD}$ & $\mathrm{kD}$ \\
\hline No serum & $41 \pm 2$ & $47 \pm 1 \dagger$ & $38 \pm 1$ & $39 \pm 1$ & $35 \pm 2$ & $35 \pm 0.4$ & $33 \pm 1$ & $33 \pm 0.5$ \\
\hline \multirow[t]{4}{*}{ With serum } & $43 \pm 1$ & $49 \pm 2 \dagger$ & $46 \pm 1$ & $50 \pm 1 \dagger$ & $42 \pm 2$ & $38 \pm 2$ & $36 \pm 1$ & $32 \pm 1 \dagger$ \\
\hline & \multicolumn{4}{|c|}{ Infasurf +} & \multicolumn{4}{|c|}{ Native surfactant +} \\
\hline & & HA 1240 & HA 250 & HA 100 & & HA 1240 & HA 250 & HA 100 \\
\hline & No HA & $\mathrm{kD}$ & $\mathrm{kD}$ & $\mathrm{kD}$ & No HA & $\mathrm{kD}$ & $\mathrm{kD}$ & $\mathrm{kD}$ \\
\hline No serum & $36 \pm 1$ & $44 \pm 3$ & $33 \pm 1$ & $31 \pm 1$ & $35 \pm 0.4$ & $44 \pm 1 \dagger$ & $33 \pm 0.3$ & $33 \pm 0.4 \dagger$ \\
\hline With serum & $39 \pm 3$ & $52 \pm 3 \dagger$ & $36 \pm 1$ & $33 \pm 1$ & $35 \pm 1$ & $46 \pm 2 \dagger$ & $36 \pm 1$ & $34 \pm 1$ \\
\hline
\end{tabular}

* Values obtained after 5 min of cycling. Values represent means $\pm \operatorname{SEM}(n=5)$.

$\dagger p \leq 0.05$ for comparisons of HA-supplemented samples with HA-free samples using ANOVA and corrected for multiple comparisons by Tukey or Kruskal Wallis tests.

maximum surface tensions with the lower molecular weight HAs (Table 1).

\section{DISCUSSION}

In this study, we found that HA over a range of molecular weights is able to substantially improve most measures of surface activity of Survanta, Curosurf, Infasurf, and native calf surfactant especially after inactivation with serum. The finding that HA is effective with each of the surfactants tested is in contrast to results with nonionic polymers in which dextran was found to be significantly more effective with Curosurf than PEG, and PEG was more effective with Survanta than dextran (28). These results suggest that ionic and nonionic polymers may affect surfactants by different mechanisms.

Until some years ago, the main role of HA was thought to be one of the inactive fillers ("ground substance") of the interstitial space. It is present in high concentrations in the vitreous humor, synovial fluid, and umbilical cord. More recently, HA has been found to interact with a number of receptor proteins, such as CD44 and RHAMM, thereby acting to modulate inflammatory reactions, cell growth, and migration during embryo- and tumorigenesis. In alveolar fluid, HA is reported to have molecular weights of $\sim 220 \mathrm{kD}$ with a concentration of $\sim 4$ $\mu \mathrm{g} / \mathrm{mL}$, based on the amount retrieved from bronchoalveolar lavage matched with calculations of the alveolar aqueous subphase volume (29). This may be an underestimation because of the inefficiency of removal of protein-bound HA and because of difficulties in ascertaining subphase volumes. The alveolar concentrations of surfactant under normal and abnormal conditions are also difficult to measure accurately.

How does HA interact with pulmonary surfactant to cause these alterations in surface activity? The properties of HA include ability to self-aggregate, interactions with proteins, and ability to bind up to one thousand times its own weight of water $(23,30)$. By binding water molecules, HA (like PEG and dextran) can increase the concentration of some molecules in the nonbound water and by this mechanism may act to segregate surfactant from serum constituents and thus mitigate inactivation. HA forms a three-dimensional macromolecular mesh in water that may also act to separate inactivating substances from surfactant by acting as a size-discriminating filter
(31). Phospholipids in the presence of HA tend to form lipid aggregates (17). HA may also stabilize surfactant phospholipids at the air-water interface and/or increase surface adsorption of subphase lipids. HA in addition to its hydrophilic properties has hydrophobic regions created by its physical shape that could potentially serve as interaction sites for the hydrophobic surfactant proteins B and C. Several of these attributes and effects of HA are shared by SP-A, such as prevention of surfactant inactivation, improvement of surface activity under some conditions, binding of phospholipids, and synergy with SP-B.

The possibility of HA's binding albumin has been addressed by a number of investigators. Gramling et al. (32) inferred from electrophoretic mobility studies that HA forms stable complexes with albumin. They also found that some free HA exists even with an albumin excess. Gold et al. (33) found binding of HA and other glycosaminoglycans to albuminagarose columns. However, they also found that this binding was not observed unless the salt concentration was far below physiologic ranges that we used.

The reason for the increased maximum surface tension with high molecular weight HA is not clear. This finding is not present with the two HAs that have molecular weights closer to those reported for alveolar lavage.

Although HA has beneficial in vitro interactions with surfactant, it is difficult to predict what the in vivo effects would be, granted the largely unknown subphase concentrations of surfactant, HA and other endogenous polymers, and serum under normal and abnormal conditions. Various lung injuries result in either increased or decreased levels of HA $(34,35)$. Inflammatory processes have been found to be affected in vivo by HA in part dependent on molecular weight (36-38). With repeated aerosolization of $100-\mathrm{kD}$ HA into lungs of guinea pigs that were injured with elastase, Cantor et al. (39) found a decrease in elastic fiber injury and no adverse morphologic changes in the lungs attributable to HA. The existing evidence suggests that the administration of HA into alveoli will not be harmful and may prove to be beneficial.

\section{CONCLUSION}

In summary, HA improves the surface activity of four different pulmonary surfactants, especially in the presence of 
serum inactivation. Therefore, HA may be a useful additive to current formulations of surfactants for therapeutic use if animal studies find both effectiveness and safety. Although dextran, PEG, and HA all have been approved by the Food and Drug Administration for purposes in humans, use of an endogenous substance (HA) as a surfactant additive seems attractive. These results also add in vitro evidence in support of the hypothesis that HA may have a normal role in the function of surfactant at the alveolar surface.

Acknowledgments. We appreciate helpful comments and critical review of the manuscript by Coralie Alonso. We also thank Cynthia Brown for measuring the lipopolysaccharide concentration in the HA.

\section{REFERENCES}

1. Clements JA 1997 Lung surfactant: a personal perspective. Annu Rev Physiol 59:1-21

2. Avery ME 2000 Surfactant deficiency in hyaline membrane disease. Am J Respir Crit Care Med 161:1074-1075

3. Suresh GK, Soll RF 2001 Current surfactant use in premature infants. Clin Perinatol 28:671-694

4. Gregory TJ, Steinberg KP, Spragg R, Gadek JE, Hyers TM, Longmore WJ, Moxley MA, Cai GZ, Hite RD, Smith RM, Hudson LD, Crim C, Newton P, Mitchell BR, Gold AJ 1997 Bovine surfactant therapy for patients with acute respiratory distress syndrome. Am J Respir Crit Care Med 155:1309-1315

5. Jobe AH, Ikegami M 1997 Surfactant for acute respiratory distress syndrome. Adv Intern Med 42:203-230

6. Taeusch HW 2000 Treatment of acute (adult) respiratory distress syndrome: the holy grail of surfactant therapy. Biol Neonate 77(suppl 1):2-8

7. Anzueto A 2002 Surfactant supplementation in the lung. Respir Care Clin N Am $8: 211-236$

8. Notter RH 2000 Lung Surfactants: Basic Science and Clinical Applications. Marcel Dekker, New York, pp 207-208

9. Gupta M, Hernandez-Juviel JM, Waring AJ, Walther FJ 2001 Function and inhibition sensitivity of the N-terminal segment of surfactant protein B (SP-B1-25) in preterm rabbits. Thorax 56:871-876

10. Taeusch HW, Lu KW, Goerke J, Clements JA 1999 Nonionic polymers reverse inactivation of surfactant by meconium and other substances. Am J Respir Crit Care Med 159:1391-1395

11. Kobayashi T, Ohta K, Tashiro K, Nishizuka K, Chen WM, Ohmura S, Yamamoto K 1999 Dextran restores albumin-inhibited surface activity of pulmonary surfactant extract. J Appl Physiol 86:1778-1784

12. Lu JJ, Cheung WWY, Yu LMY, Policova Z, Li D, Hair ML, Neumann AW 2002 The effect of dextran to restore the activity of pulmonary surfactant inhibited by albumin. Respir Physiol Neurobiol 130:169-179

13. Lu KW, Taeusch HW, Robertson B, Goerke J, Clements JA 2000 Polymer-surfactant treatment of meconium-induced acute lung injury. Am J Respir Crit Care Med 162:623-628

14. Lu KW, Taeusch HW, Robertson B, Goerke J, Clements JA 2001 Polyethylene glycol/surfactant mixtures improve lung function after $\mathrm{HCl}$ and endotoxin lung injuries. Am J Respir Crit Care Med 164:1531-1536

15. Kobayashi T, Tashiro K, Cui X, Konzaki T, Xu Y, Kabata C, Yamamoto K 2001 Experimental models of acute respiratory distress syndrome: clinical relevance and response to surfactant therapy. Biol Neonate 80(suppl 1):26-28
16. Tashiro K, Cui XG, Kobayashi T, Curstedt T, Robertson B 2003 Modified protocols for surfactant therapy in experimental meconium aspiration syndrome. Biol Neonate $83: 49-56$

17. Pasquali-Ronchetti I, Quaglino D, Mori G, Bacchelli B, Ghosh P 1997 Hyaluronanphospholipid interactions. J Struct Biol 120:1-10

18. Sahu SC, Tanswell AK, Lynn WS 1980 Isolation and characterization of glycosaminoglycans secreted by human foetal lung type II pneumocytes in culture. J Cell Sci 42:183-188

19. Skinner SJ, Post M, Torday JS, Stiles AD, Smith BT 1987 Characterization of proteoglycans synthesized by fetal rat lung type II pneumonocytes in vitro and the effects of cortisol. Exp Lung Res 12:253-264

20. Stratton CJ, Douglas WJ, McAteer JA 1978 The surfactant system of human fetal lung organotypic cultures: ultrastructural preservation by a lipid-carbohydrate retention method. Anat Rec 192:481-92

21. Scarpelli EM, Clutario BC, Taylor FA 1967 Preliminary identification of the lung surfactant system. J Appl Physiol 23:880-886

22. Nir I, Pease DC 1976 Polysaccharides in lung alveoli. Am J Anat 147:457-469

23. Bray BA 2001 The role of hyaluronan in the pulmonary alveolus. J Theor Biol 210:121-130

24. Bligh EG, Dyer WJ 1959 A rapid method of total lipid extraction and purification. Can J Biochem Physiol 37:911-917

25. Bartlett GR 1959 Phosphorus assay in column chromatography. J Biol Chem 234:466-468

26. Boncuk-Dayanikli P, Taeusch HW 1995 Essential and nonessential constituents of exogenous surfactants. In: Robertson B, Taeusch HW (eds) Surfactant Therapy for Lung Disease. Marcel Dekker, New York, pp 217-238

27. Putz G, Goerke J, Taeusch HW, Clements JA 1994 Comparison of captive and modified pulsating bubble surfactometers. J Appl Physiol 76:1425-1431

28. Lu KW, Taeusch HW 2001 Polymer effects differ with Survanta, Curosurf and Infasurf. J Investig Med 49:28A

29. Bastacky J, Lee CYC, Goerke J, Koushafar H, Yager D, Kenaga L, Speed TP, Chen YA, Clements JA 1995 Alveolar lining layer is thin and continuous: low-temperature scanning electron microscopy of rat lung. J Appl Physiol 79:1615-1628

30. Ogston AG, Steiner JE 1951 The dimensions of the particle of hyaluronic acid complex in synovial fluid. Biochem J 49:585-590

31. Laurent TC 1970 Structure of hyaluronic acid. In: Balazs EA (ed) Chemistry and Molecular Biology of the Intercellular Matrix. Academic Press, London, pp 703-732

32. Gramling E, Niedermeier W, Holley HL, Pigman W 1963 Some factors affecting the interaction of hyaluronic acid with bovine-plasma albumin. Biochim Biophys Acta 69:552-558

33. Gold EW 1980 An interaction of albumin with hyaluronic acid and chondroitin sulfate: a study of affinity chromatography and circular dichroism. Biopolymers 19:1407-1414

34. Juul SE, Kinsella MG, Jackson JC, Truog WE, Standaert TA, Hodson WA 1994 Changes in hyaluronan deposition during early respiratory distress syndrome in premature monkeys. Pediatr Res 35:238-243

35. Juul SE, Kinsella MG, Truog WE, Gibson RL, Redding GJ 1996 Lung hyaluronan decreases during group B streptococcal pneumonia in neonatal piglets. Am J Respir Crit Care Med 153:1567-1570

36. Savani RC, Hou G, Liu P, Wang C, Simons E, Grimm PC, Stern R, Greenberg AH, DeLisser HM, Khalil N 2000 A role for hyaluronan in macrophage accumulation and collagen deposition after bleomycin-induced lung Injury. Am J Respir Cell Mol Biol 23:475-484

37. McKee CM, Penno MB, Cowman M, Burdick MD, Strieter RM, Bao C, Noble PW 1996 Hyaluronan fragments induce chemokine gene expression in alveolar macrophages. J Clin Invest 98:2403-2413

38. Teder P, Vandivier RW, Jiang D, Liang J, Cohn L, Pure E, Henson PM, Noble PW 2002 Resolution of lung inflammation by CD44. Science 296:155-158

39. Cantor JO, Shteyngart B, Cerreta JM, Liu M, Armand G, Turino GM 2000 The effect of hyaluronan on elastic fiber injury in vitro and elastase-induced airspace enlargement in vivo. Proc Soc Exp Biol Med 225:65-71 